\title{
The Spoils of the Victors: Captain Ferdinand Winslow and the 1863 Curtis Court of Inquiry
}

\author{
ANDERS BO RASMUSSEN
}

ON THE EVENING of October 3, 1861, the 32-year-old quartermaster Ferdinand Winslow of Marion, Iowa, walked across Benton Barracks's rolling campground on his way to the encampment center. There, on the outskirts of St. Louis in a shining white villa encircled by a snow-white fence, Brigadier General Samuel Ryan Curtis, "a very fine looking elderly Gentleman," had made his temporary headquarters. ${ }^{1}$ From his military home Curtis followed camp activities, but this particular evening the commanding officer's duty took a backseat to leisure. Thus, Winslow, accompanying his commanding officer in the Ninth Iowa Infantry Regiment, William Vandever, spent a pleasant, musical evening at Curtis's house, subsequently reporting home that he "was invited to come and go in the house any time." 2

Curtis, Vandever, and Winslow had all volunteered for military service within months of the Civil War's outbreak, and people

The author would like to thank the State Historical Society of Iowa for the research grant that provided financial support, editor Marvin Bergman and the journal's reviewers for helpful suggestions, and Dr. Michael Douma for valuable assistance in the National Archives in Washington, DC.

1. Ferdinand Sophus Winslow, "Benton Barracks, St. Louis. 2 October 1861," Ferdinand Sophus Winslow Letters, September 1861-February 1862 (hereafter cited as Winslow Letters), Special Collections, University of Iowa Libraries, Iowa City.

2. F. S. Winslow, “Benton Barracks, St. Louis. 4 October 1861," Winslow Letters.

THE ANNALS OF IOWA 76 (Spring 2017). C State Historical Society of Iowa, 2017. 
back in Iowa knew them well. Curtis and Vandever were closely associated with the Republican Party and had represented Iowans' antislavery interests in Congress leading up to the war. Winslow, while lesser known, had achieved a certain stature in eastern Iowa, where, according to a local newspaper, he was considered "one of the most enterprising, energetic business men." 3

These three officers shared a distaste for slavery, which, along with their fierce personal ambition, formed a bond between them that only grew stronger as military action drew nearer. ${ }^{4}$ Winslow, a well-educated Danish immigrant, received "very affectionate letters" from Vandever, rode regularly with Curtis's son Henry ("I really love that man, and he returns my feelings"), and corresponded with Curtis's daughter. ${ }^{5}$ Winslow was even handpicked by General Curtis to serve as the Army of the Southwest's chief quartermaster with the rank of captain before its 1862 spring campaign, which, as it turned out, brought "a strategy of war by emancipation" into Arkansas. ${ }^{6}$

3. Samuel Prentis Curtis, "The Army of the South-West, and the First Campaign in Arkansas," Annals of Iowa, 1st series, 4 (1866), 627; F. S. Winslow, "Benton Barracks, St. Louis. Monday Evening October 7th 186111 O'clock," Winslow Letters; Scribbler [Ferdinand Winslow], "From the Iowa Ninth," Dubuque Daily Times, 2/15/1862; "Personal," Dubuque Weekly Times, 1/10/1861.

4. Ferdinand S. Winslow, "Henry Ward Beechers Prædikener Om Negerne I Amerika [Henry Ward Beecher's Sermons on the Negroes in America]," in Kirkelig Maanedstidende [Church Monthly], ed. Kirkens Præster i Amerika (Inmansville, WI, 1857). In this article, directed at fellow Scandinavian Americans, Winslow wrote glowingly about Henry Ward Beecher's abolitionist sermons. See also F. S. Winslow, "Benton Barracks, St. Louis. 4 October 1861"; "Springfield, Mo. March 15 1862"; and "In Camp near Rolla, Tuesday Morning 3 O'clock. 28 January 1862," all in Winslow Letters.

5. F. S. Winslow, "Pacific, Mo. Thursday 5th December 1861"; "Pacific, Mo. 15 January 1862"; "Springfield Mo. February 171862 Monday"; "Pacific, Mo. November 26 1861," all in Winslow Letters. Winslow's relationship to General Curtis often included invitations to dinner, as was the case on November 26, 1861, when "the Colonel [Vandever], the Major [Coyl], and I were welcome guests at General Curtis's house." F. S. Winslow, "Pacific, Mo. November 26 1861," Winslow Letters.

6. Winslow wrote, "I told you last in a hurried letter that Major General Curtis had appointed me Chief Quartermaster and Commissary of the whole army." He added that he was relieving Captain Philip Sheridan (of later Cavalry Corps fame under Ulysses S. Grant), "who was ordered under arrest to St. Louis." F. S. Winslow, "Springfield. March 22 1862. Saturday Night," Winslow Letters. See also Andrew Zimmermann, "From the Rhine to the Mississippi," Journal of the Civil War Era 5 (2015), 27. 
The three men's antislavery sympathies were forcefully tested, however, as Curtis's army reached the banks of the Mississippi River and occupied Helena in the summer of 1862. Winslow, who before the Civil War had publicly advocated emancipation, equality, and liberty for "all human beings," chose money over abolitionist values after his arrival at Helena. ${ }^{7}$ In that prioritization Winslow was hardly alone. As evidenced by a subsequent "court of inquiry," during the occupation of eastern Arkansas several other Union officers seized the chance for private profit, which weakened the army's ability to protect and provide for former slaves. In short, selling cotton for private gain trumped the antislavery sentiments that otherwise permeated General Curtis's officer corps. ${ }^{8}$

GENERAL CURTIS'S 1862 spring campaign got off to a successful start when the Army of the Southwest defeated Confederate adversaries at the Battle of Pea Ridge in northwestern Arkansas in early March, thereby opening a path to Arkansas's heartland. As Curtis moved his troops southeast down the White River, his army directly and indirectly altered the local patterns of commerce and, more importantly, practices of ownership in the areas they occupied. The resulting changes likely played a part in leading Major-General Henry Halleck to appoint Curtis as military governor of Arkansas on May 12 and to task him with removing untrustworthy civil authorities and appointing loyalists in an attempt to bring stability to the area. ${ }^{9}$

After a punishing trek across Arkansas in early July, during which "thousands of slaves abandoned their masters" and joined the Union army's line of march, Curtis's troops, led by Winslow's foraging party, reached the banks of the Mississippi River on July

7. Ferd. S. Winslow, “Brooklyn. 11th Septbr. 1856. Religion Og Politik [Brooklyn. September 11th, 1856. Religion and Politics]," in Kirkelig Maanedstidende, ed. Kirkens Præster i Amerika (Inmansville, WI, 1856).

8. Zimmermann, "From the Rhine to the Mississippi," 25.

9. Robert N. Scott, The War of the Rebellion: A Compilation of the Official Records of the Union and Confederate Armies, ser. 1, vol. 13 (Washington, DC, 1885), 378; Earl J. Hess, The Civil War in the West: Victory and Defeat from the Appalachians to the Mississippi (Chapel Hill, NC, 2012), 70. 
12. ${ }^{10}$ Coincidentally, the Army of the Southwest thereby occupied the city of Helena the same day that Congress put the finishing touches on the Second Confiscation Act, which contained wide-ranging options for emancipating slaves. ${ }^{11}$

The confiscation bill, signed by Abraham Lincoln on July 17, 1862, definitively sanctioned previous ad hoc practices of "employing fugitive" slaves, based on the belief that it was better than "returning them to their owners, where their labor would support the rebellion." The law also underlined that " "property in man' was not constitutionally protected." At the core of the law was a distinction between real estate and slaves: the former was protected from confiscation by the U.S. Constitution while the latter, according to abolitionist lawyers and Republican politicians, was not. In essence, it thereby became "easier for Republicans to free a slave than to confiscate a house." 12 As General Curtis later wrote, the responsibility for handling these interrelated issues of confiscation, property, and slavery fell on the commanding general and his officers, since "all the civil tribunals and social organizations were thrown into utter confusion or destruction" by the Union army's occupation. ${ }^{13}$

The situation around Helena was not unique among Federal forces in the South. On July 22 Secretary of War Edwin Stanton directed military commanders to "employ as laborers ... so many persons of African descent as can be advantageously used." He also instructed them to pay "reasonable wages for their labor." In Louisiana General Benjamin Butler immediately took advantage of this directive. Over the course of three months, Butler ordered slaves released "from confinement" of disloyal masters, directed plantation owners to pay black workers wages of ten dollars per month, and took over sugar plantations to help "defray the cost of a massive relief program" that was designed to

10. Carl H. Moneyhon, "From Slave to Free Labor: The Federal Plantation Experiment in Arkansas," in Civil War Arkansas: Beyond Battles and Leaders, ed. Anne J. Bailey and Daniel E. Sutherland (Fayetteville, AR, 2000), 178.

11. James Oakes, Freedom National: The Destruction of Slavery in the United States, 1861-1865 (New York, 2013), 249.

12. Ibid., 233, 39, 52-54.

13. Samuel R. Curtis, "Keokuk Iowa Nov 8th 1863 His Excellency Abraham Lincoln President of the US," folder 4, Samuel Ryan Curtis Papers, 1859-1863, Manuscripts Collection, Abraham Lincoln Presidential Library, Springfield, IL. 
"feed and house thirty-two thousand desperate whites and ten thousand blacks, mostly women and children, who otherwise faced starvation." 14 As it turned out, Butler's problems-and his solutions - were in many ways mirrored by Curtis's actions on the banks of the Mississippi.

In July 1862 Helena was "the southernmost point on the Mississippi river held by Federal troops." Thus it was quickly transformed into a hub for runaway slaves. Caring for "vagrant negroes ... robbed of means of subsistence by guerillas and our own half famished soldiers" became one the army's biggest logistical challenges. ${ }^{15}$ A letter to Winslow on July 24, 1862, from Acting Assistant Quartermaster B. O. Carr asking for help and direction revealed the extent of the problem.

Capt., There is a perfect 'cloud' of negroes being thrown upon me for Sustenance and Support, out of some 50 for whom I draw rations this morning but twelve were working stock, all the rest being women and children. What am I to do with them? If this taking them in and feeding them is to be the order of the day, would it not be well to have some competent man employed to look after them and keep their time; draw their rations; look after their Sanitary Condition. Etc. Etc? As it is, although it is hard to believe that such things can be, [white] Soldiers \& Teamsters are according to common reports indulging in intimacy with them which can only be accounted for by the doctrine of Total Depravity. ${ }^{16}$

The plight of these runaway slaves and the challenge of dealing with the vast stores of Confederate cotton on plantations abandoned by white owners were "peculiarly perplexing" problems for Curtis's army, since no instructions had arrived from the Treasury Department or other governmental agencies. ${ }^{17}$ Curtis's instructions from his superior, Henry Halleck, commanding the

14. Oakes, Freedom National, 248-54.

15. Earl J. Hess, "Confiscation and the Northern War Effort: The Army of the Southwest at Helena," Arkansas Historical Quarterly 44 (1985), 56.

16. B. O. Carr, "Helena, Ark. July 24th 1862," box 2, Testimonies in investigation of Curtis for alleged cotton speculation. 1862-1863, Samuel Ryan Curtis Papers, State Historical Society of Iowa, Des Moines (SHSI).

17. N. P. Chipman, “Washington D.C. Nov. 10. 1863. His Excellency the President of the United States," folder 4, Samuel Ryan Curtis Papers, 1859-1863, Manuscripts Collection, Abraham Lincoln Presidential Library, Springfield, IL. 
Department of the Mississippi, simply advised him to "act as your own judgement dictates." 18 Curtis's judgment dictated that former slaves, "claimed as property by persons in the rebel service," deserved "free papers" and an economic interest in the fruits of their own labor. ${ }^{19} \mathrm{He}$ wrote to Lincoln that he "interested the negroes in saving it [cotton] from thieves, hurrying it to market, and expediting their departure" from Helena. ${ }^{20}$

As Curtis was keenly aware, many people, both civilian and military, were interested in the economic fruits of the former slaves' labor. The Union army's occupation of the Mississippi River down to Memphis, Earl Hess notes, "led to a flood of Northern vendors looking for ways to make a quick profit," and cotton was by far the most attractive commodity. ${ }^{21}$ It therefore fell on the local military commanders to set the boundaries around the trade, as cotton buyers were dependent on the army for transportation.

However, Curtis's quartermaster, Ferdinand Winslow, interpreted the general's directives on matters such as contraband slaves, forage acquisition, and supply management somewhat loosely. "The most unlimited power is given me by the General," wrote Winslow back in April 1862 about a relationship that seemingly did not change in the following months. ${ }^{22}$ Winslow, it turned out, ended up with a personal economic interest in the fruits of the freed slaves' labor, which, by extension, diverted resources away from the people that, according to B. O. Carr, needed the "sustenance and support" of the Union army the most.

Winslow's actions, while perhaps expressing a rational choice from a private economic perspective, therefore contradicted federal and military policy as well as Winslow's own public writings

18. H. W. Halleck, "Head Quarter Department of the Mississippi St Louis. Mo. July 19th 1862," box 2, Samuel Ryan Curtis Papers, SHSI. According to Hess, "Confiscation and the Northern War Effort," 68, "Beyond advising their subordinates to follow Treasury Department regulations, authorities gave no further instructions on cooperation with the civilians."

19. Chipman, "Washington D.C. Nov. 10. 1863. His Excellency the President of the United States."

20. Samuel R. Curtis, "Keokuk Iowa Nov 8th 1863 His Excellency Abraham Lincoln President of the US."

21. Hess, Civil War in the West, 70-72.

22. F. S. Winslow, “Rolla Sunday April 26th 1862,” Winslow Letters. 
prior to the outbreak of the Civil War. In late 1856 Winslow, inspired by Henry Ward Beecher's abolitionist sermons in Brooklyn, had reminded his fellow Scandinavian immigrants in the United States that a good cause was one that fought for "serfdom's dissolution and equality and freedom between all human beings." 23

Curtis's policies around Helena - freeing runaway slaves, allowing them to sell cotton, and permitting them to travel north with free papers - were important steps toward ensuring equality and freedom, but, as it turned out, the commanding general's directives opened him up to criticism from more conservative army officers. ${ }^{24}$ In addition, by allowing some merchants but not others to trade within Union lines, Curtis drew the ire of rejected traders. When it became apparent that some of his subordinates were profiting privately from the cotton trade, the commanding general became vulnerable to censure. ${ }^{25}$

Events in and around Helena under General Curtis challenged military doctrine to such an extent that when he was transferred to a higher command in St. Louis, Frederick Steele, his successor and former division commander, quickly "reversed most of his liberal policies regarding African Americans at Helena" but continued to allow the trade in cotton. Steele, an opponent of emancipation, later derided the Army of the Southwest's condition in a letter to President Lincoln.

When I assumed command of the Army of the South West in August, 1862, our camps and the town of Helena were overrun with fugitive slaves of both sexes, from infancy up to old age. Vice, immorality and distress, the usual accompaniments of vagrancy and destitution followed. The women were prostituted to a fearful extent, I believe by officers as well as by men, the feeble died in the streets in great numbers, from neglect and want. Disease and the elements of disorganization were introduced into my command by these miserable creatures. ${ }^{26}$

23. Winslow, "Brooklyn. 11th Septbr. 1856. Religion Og Politik."

24. "The Cotton Court of Inquiry; Testimony of Maj.-Gen F. Steele Important Developments Gen. Curtis Implicated," New York Times, 5/24/1863.

25. Hess, Civil War in the West, 73.

26. Frederick Steele, "Head Quarters 1st Division 13th Army Corps. In Camp near Vicksburg Miss. Feby. 15th 1863. To His Excellency the President," General Frederick Steele Papers, M0191, Special Collections, Stanford University Libraries, Stanford, CA. 
Thus, Steele placed blame for the army's poor condition on fugitive slaves, but his actions after assuming command also made it clear that he disagreed with Curtis's decisions to confiscate and sell cotton for the benefit of former slaves.

A more serious challenge to actions taken under Curtis's command came in February 1863, when the War Department established a "Court of Inquiry on the Sale of Cotton and Produce" that incidentally revealed much about white officers' attitudes toward race and social advancement. ${ }^{27}$ During the court of inquiry's proceedings, it was disclosed that not all the cotton had been sold for the benefit of Arkansas's local slave population or the U.S. government. On the contrary, the court of inquiry indicated that Curtis's officers often bent the rules, and on a few occasions even risked soldiers' lives, to enrich themselves or unscrupulous merchants.

As chief quartermaster for the Army of the Southwest, Ferdinand Winslow played a key - but previously unexamined - role in this ethically questionable transportation of confiscated cotton on the Mississippi River. Winslow, a relatively successful banker before the war, sold horses, demanded a stake in a local business, and in all likelihood also profited privately from cotton sales that Curtis intended to help support the numerous runaway slaves living under desperate conditions. In other words, Winslow took advantage of his position as chief quartermaster, in several instances choosing pecuniary gain at the indirect expense of his professed abolitionist values of "equality and freedom." 28 Yet the court of inquiry demonstrated that Winslow was far from the only Union officer for whom these actions revealed a contradiction.

"CRIME opens many windows on the past," note historians Edward Muir and Guido Ruggiero. Court documents reveal "otherwise invisible or opaque realms of human experience" even as they serve as "scripts in a theater of authority." Thus, an analysis

27. Edward Muir and Guido Ruggiero, "Afterword: Crime and the Writing of History," in History from Crime, ed. Edward Muir and Guido Ruggiero (Baltimore, 1994), 227-28; Alison Clark Efford, "The Appeal of Racial Neutrality in the Civil War-Era North: German Americans and the Democratic New Departure," Journal of the Civil War Era 5 (2015), 69.

28. Winslow, "Brooklyn. 11th Septbr. 1856. Religion Og Politik." 
of Winslow's explanations of his actions in Helena, Arkansas, can be used as important evidence in a larger historical examination of confiscation policies in the area. ${ }^{29}$

On March 19, 1863, Major General Samuel R. Curtis took the witness stand in St. Louis to defend his actions the previous year. The court of inquiry, which had been officially ordered by General Halleck a month earlier, charged "three competent officers," among them Irwin McDowell, who had commanded the Union forces at the Battle of Bull Run in July 1861, with investigating the following potential transgressions in Helena.

1st Whether any and what officers in the service have been engaged, or directly or indirectly participated in traffic in Cotton or other produce on the Mississippi River or its tributaries, to what extent, under what circumstances, and with all the particulars of the transactions. 2. Whether any and what Military Officers have granted licenses or permits for trade to who, at what time, with all the particulars thereof.

3. Whether any and what Military Officers have used or permitted the use of Government transportation, or other public property for private purposes.

4. And also to enquire, and report upon such other matters as may be directed. ${ }^{30}$

From the first day the appointed court met in St. Louis it was clear that the its mandate was broad enough to incriminate most Union officers called to testify. Yet some officers were clearly more central to the investigation than others. With his opening answer, Curtis mentioned that "Capt Winslow" had "engaged in the purchase and sale of cotton" but denied that he himself, or Winslow, had been involved in any wrongdoing. In fact, Curtis denied knowledge of fraudulent behavior among any military officers under his command. 31

29. Muir and Ruggiero, "Introduction: The Crime of History," vii-ix, point out that "everyone who speaks during a criminal procedure does so under the constraints of authority, which means all speech has been conditioned by threats of punishment." See also Carlo Ginzburg, "Checking the Evidence: The Judge and the Historian," Critical Inquiry 18 (1991), 90-91; and Oakes, Freedom National, 248. 30. "Proceedings and Report of a Court of Inquiry on the Sale of Cotton and Produce at St. Louis, Missouri, 1863. Volume 1," Record Group 159, Records of the Office of the Inspector General, National Archives, Washington, DC.

31. Ibid., 5 . 
Yet Curtis also clearly placed the overall responsibility for transportation and trade on his quartermasters. As he told the court, "All their contracts and everything of that kind I never see." When Curtis was initially asked to state whether, in his knowledge, any officers had participated, directly or indirectly, in the cotton trade on the Mississippi River, he again specifically mentioned his chief quartermaster.

I turned over cotton that I considered the spoils of the Victors and contraband of war to Brig. Gen. C. C. Washburne. I directed him to sell a portion of it at Helena for the purpose of feeding the negroes of the plantation who ran into my lines and were starving for food. The remainder I told him to forward to New York and have sold for the benefit of the U.S.

I think subsequently on the arrival of my chief QuarterMaster Capt Winslow, the disposition of the Cotton was turned over to the QuarterMaster with my approval, to be confiscated, and the proceeds to be turned over to the U.S. That is all, I think, that I know of any officer in the U.S. Army having engaged in the purchase or sale of cotton. ${ }^{32}$

Curtis, who frequently testified that records no longer existed, and many times never had existed, could often only refer to subordinates when asked about a paper trail for the appointed court officers to follow. "My Quarter Master reported that he had made full account of the whole matter" was a frequent reply from Curtis. "I do not think I took an invoice at all, but there was a large amount of cotton taken mainly from the vicinity of Helena." 33

According to Curtis, the confiscated cotton was shipped north for five dollars per bale. When Winslow was summoned to appear in court four days later, he recalled some details differently. Winslow testified, “I don't know of the regulation as to $5 \$$ per bale, Genl Curtis instructed me to charge the usual rates, I fixed it at $4 \$$ per bale after consulting the merchants in town." Like Curtis, he, too, had not left much of a paper trail to document his dealings in Helena. ${ }^{34}$

32. Ibid., 13, 3-5.

33. Ibid., 6 .

34. Ibid., 51-56. Variations on the following exchange were repeated throughout the trial. "Have you any of the returns of the [river boat] Captains for freights and passage taken by them? [Winslow's answer] I don't think I have." 
This was only one of several instances of discrepancies between Winslow's testimony and that of other witnesses. For example, Winslow claimed to have deposited $\$ 15,427.90$ of government money in a state bank, but the cashier testified that only $\$ 11,262.65$ was deposited. ${ }^{35}$ Even more serious was the case of the so-called "Cold Water" cotton that the court believed had been "hauled to the Mississippi River" using U.S. government teams and even imperiling soldiers' lives. In this case, Winslow explained his role as follows:

[An officer] reported to me that an expedition under Col Hovey's direction had been some 60 miles in Mississippi and brought down on Government teams some 300 Bales of Cotton, and that in this expedition several men of the 33rd Illinois and 11th Wisconsin had been wounded, I reported this at once to General Steele in person and he ordered me to send a Ferry boat down and seize the cotton which was claimed to be owned by one Mr. Grant who said he had purchased it. ${ }^{36}$

In essence, Winslow claimed that he had been ordered by General Steele, who took command of the army on August 29, to seize the cotton for the American government, but when Steele was called to testify, he adamantly denied the quartermaster's claim. Moreover, W. L. Grant testified that "Captain Winslow" told him "that General Steele had left him [Winslow] no written instructions but had directed him to do as he pleased with the cotton that is, sell it there, or ship it north." Again, this was denied by Steele when he took the stand. "I supposed it would be sold for the benefit of the Government. While I was absent at Cairo Captain Winslow for some cause best known to himself released this cotton. He had no authority from me to release it. None of my staff Officers had instructions about this cotton." 37

Thus, W. L. Grant was able to sell for private gain cotton that had been seized by the U.S. Army and ostensibly ordered by General Steele to "be sold for the benefit of the Government." Grant paid a Doctor O'Reilly $\$ 8,000$ to obtain a release for the

35. Ibid., 66. Later, Winslow claimed that he had deposited government money in several different accounts.

36. Ibid., 65-66.

37. Ibid., 609 
seized cotton from Winslow so it could be sold by Grant. O’Reilly accomplished that in "about four hours" despite a promise not to "share the eight thousand dollars with any officer." 38 O'Reilly did, however, in a later transaction tell Grant that "he had to divide with someone." 39 Thus, when Steele testified that "Captain Winslow for some cause best known to himself released the cotton," it is not unlikely, as we shall see, that the cause was some kind of private gain. As Hess has argued, "Few officers traded in cotton directly, preferring to aid speculators in locating or transporting it." 40

The soldiers who risked their lives to seize the cotton, however, did not doubt why they were asked to do so. A. M. Koppel, a Danish immigrant soldier, writing on the subject of the socalled "Cotton expeditions" in an account published in the Scandinavian American newspaper Emigranten in October 1862, wrote, "It is no wonder that the soldiers detest these cotton expeditions, since the obtained cotton does not go to the government but to a couple of speculators staying with the brigade under the pretext of purchasing cotton." 41 This interpretation was supported by Koppel's comrade-in-arms from the 11th Wisconsin, Calvin P. Alling, who wrote in an undated memoir that "some of the regiments engaged in stealing and smuggling cotton, in the name of the Government, but shipping it north to St. Louis and selling it as their own." 42

Cotton was not the only commodity dealt in at Helena. "Officers also extended their interest to the traffic in mules, horses, and buggies that speculators developed from Helena to northern cities," writes Hess. This was almost certainly true of Winslow.

38. Ibid., 610.

39. Ibid., 611.

40. Hess, "Confiscation and the Northern War Effort," 72.

41. A. M. K., “Korrespondance Fra Det 11te Wisconsin-Regiment [Correspondence from the 11th Wisconsin Regiment]," Emigranten, 10/13/1862 (author's translation).

42. Calvin P. Alling, "Four Years in the Western Army: In the Civil War of the United States, 1861 to 1865," Reminiscences, Wis Mss 102S, Manuscript Collection, Wisconsin Historical Society, Madison, WI. Alling added, "I saw much of these operations, and in fact, with the right wing of our regiment, was on the first cotton-stealing trip across the Mississippi, to the Harding plantation, our officers being deceived as to the character of the business, and our colonel being absent." 
In letters sent home in August, the Danish immigrant wrote that he would "send some horses up today or tomorrow." Three days later, on August 22, he wrote that the horses were now on the way on the steamer Fanny Bullitt. ${ }^{43}$ Winslow apparently saw no problem with making money off of the seized contraband/property. "I am glad you have a man for the horses," he wrote. "If you have no use for them it would be better to sell them - they ought to bring 400 dollars or 500 for horses, wagons, \& harnesses." 44

It is likely that, as historian Carl Moneyhon has argued, "The profit motive ruled the experiment" at Helena. Winslow even admitted as much when he wrote to an unidentified general in the fall of 1863 about the Confederate blockade-running steamer Memphis. The rebel vessel was captured outside Charleston, South Carolina, on July 31, 1862, by the USS Magnolia and later purchased by the U.S. Navy - a purchase that yielded the Magnolia crew a significant sum of money. ${ }^{45}$ Winslow's response to the Magnolia crew's windfall reveals the Danish immigrant's mindset on the topic of private gain from military confiscation of contraband.

Life is full of Irony! . . Look at the fortunes made: The Commandant of the U.S. str "Magnolia" gets for his share \$33,318 55/100 . . . each ordinary seaman $\$ 1350[]$.83 - Now, all these men are paid - and paid liberally - for their services in the way of salaries and wages. But if some contraband property comes in their way, they are the legal recipients of big fortunes, and everybody congratulates and envies them. But if an officer or Soldier of the Army comes across a few abandoned bales of Cotton, or buys them for his own money

43. Hess, "Confiscation and the Northern War Effort:," 72; F. S. Winslow, “Helena. Arks August 19 1862," Winslow Letters; F. S. Winslow, "Helena Arks August 22 1862," ibid.

44. F. S. Winslow, "Helena. Arks. September 3 1862," Winslow Letters. See also "Proceedings and Report of a Court of Inquiry on the Sale of Cotton," 462-63. Winslow did testify to buying one horse for $\$ 150$ but did not volunteer information about other purchases. It is therefore conceivable that these horses, with wagons and harnesses, were "confiscated" by Winslow's orders for private gain. According to General Steele's testimony in the "court of inquiry" no transgression was too small to note, as it was pointed out that General Curtis also benefited privately from confiscation as he allegedly kept "two captured horses," in his stable. "The Cotton Court of Inquiry; Testimony of Maj.-Gen F. Steele Important Developments Gen. Curtis Implicated," New York Times, 5/24/ 1863.

45. Moneyhon, “From Slave to Free Labor," 192. 
and at his own risk for a small sum-lo! he is courtmartialed and possibly dishonored. What an inconsistency! 46

Winslow's letter reflected the fact that the U.S. Army was a citizen's army during the Civil War and that some citizen soldiers assumed military duty more fully than others. ${ }^{47}$ Winslow, for example, saw himself as a businessman first and a soldier second. He volunteered in September 1861 to avoid being drafted later and thereby serve with "very bad grace." He tried to resign in September 1863, citing "a large family" and the pressure to "assume control of my private business at home" or "see it entirely ruined." 48

Winslow's private business ventures likely got a boost from his trade in cotton and other contraband around Helena when those activities should have, at least under Curtis's command, helped benefit the fugitive slaves around Helena. When the court of inquiry submitted its report in July 1863, it found that Winslow had apparently "released" cotton "against authority" and that there could be no other motive than "a pecuniary one." The officers appointed to the court did, however, admit that "the evidence to this effect is circumstantial." In addition to releasing the cotton, Winslow was also found to have "traded in other property" and, according to a witness, Alfred Hopper, had pressured merchants to make him a partner in a "Sutler Store" in exchange for facilitating their trade. 49

In his letter to an unidentified general on November 18, 1863, Winslow called the report "most damning," but, as we shall see, when taking Winslow's life story into account, the court's report seems reasonable despite his prior claims of fighting for equality and liberty for all human beings.

46. Ferdinand (Fred) Sophus Winslow, "Novbr 181863 My Dear General," Missouri History Museum Digital Content, http://collections.mohistory.org/ resource/161714.html. See also "The Blockading Service: Heavy Distribution of Prize Money. How Fortunes Are Made in the Navy. Particulars of the Cargoes of the Recent Captures on the North Carolina Coast," New York Times, 11/14/1863. 47. Gary W. Gallagher and Kathryn Shively Meier, "Coming to Terms with Civil War Military History," Journal of the Civil War Era 4 (2014), 489-91.

48. Winslow, "Benton Barracks, St. Louis. 2 October 1861"; F. S. Winslow, "Office Assistant Quartermaster Nashville, Tenn. Septbr 30th 1863," in Commissioning Board Files, National Archives, Washington, DC.

49. "Proceedings and Report of a Court of Inquiry on the Sale of Cotton," 607-13. 


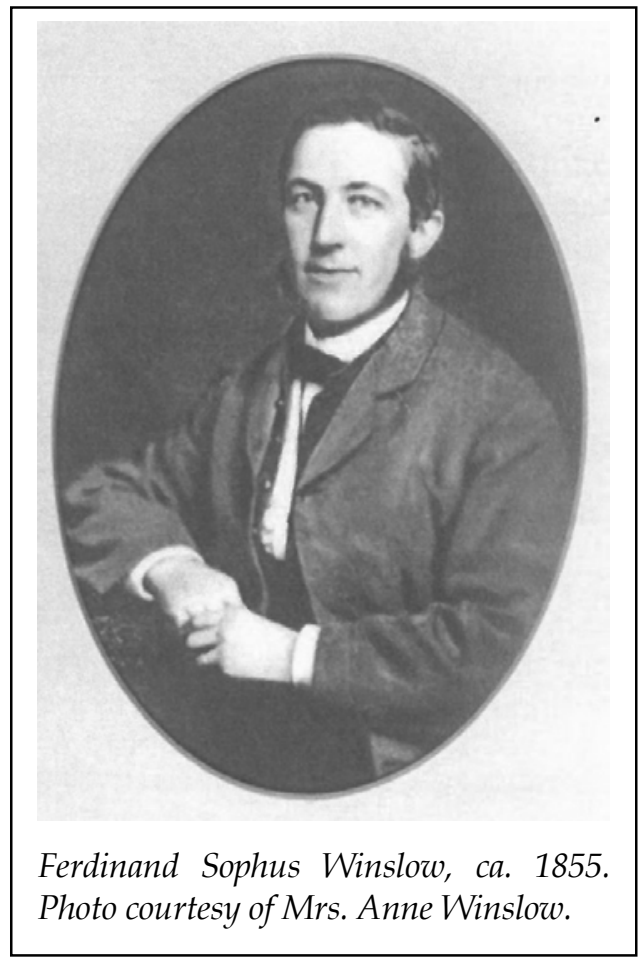

FERDINAND WINSLOW played a key role in the transportation of cotton and produce on the Mississippi River in July and August 1862. Much of the cargo was likely shipped according to government regulations, but it is difficult to ascertain for sure, as Winslow's records seemingly did not show all transactions and no "comprehensive record was kept of the number of boats used by traders." 50 What is certain is that Winslow was ultimately responsible for the river transportation and thereby also for many of the transgressions that occurred. On July 24, 1862, Winslow wrote to his wife that he had "dozens of magnificent boats running on this river," all under his "immediate command" and that he was "the last man in the Army that the General" would let go. "I dare not dream of a furlough," Winslow wrote. ${ }^{51}$

50. Hess, "Confiscation and the Northern War Effort," 70.

51. F. S. Winslow, “Helena, Arks. July 24, 1862," Winslow Letters. 
Since he was so centrally involved with river transportation, it seems unlikely that Winslow was unaware of fraudulent cotton sales, not least since Samuel Curtis's son - and Winslow's close friend-Henry Z. Curtis, for whom Winslow in 1863 named his own son, was involved in at least one instance of large-scale speculation whereby Henry Curtis and two other officers "invested money in the trade and let speculators work for them." 52 In addition, as we have seen, the logistical military power wielded by the chief quartermaster was at times used for private gain. Winslow shipped horses north, "released" cotton for a speculator, and allegedly pressured local merchants to give him a cut in their business.

This mainly circumstantial case built by the court of inquiry against Winslow gains further credence when one interprets the court case in light of other life events. Exactly ten years earlier Winslow had been released from a Copenhagen jail after serving a four-year sentence for fraud and embezzlement. ${ }^{33}$ His questionable ethics regarding finances were also manifested after the war. The money Winslow made during the Civil War as an officer and as a partner in a Marion bank allowed him, by 1865, to open a small financial business, Winslow \& Christensen, in Chicago. ${ }^{54}$ By 1872, Winslow had expanded his financial operations, opening the Scandinavian National Bank in Chicago, which quickly gained the trust of Norwegians, Swedes, and Danes. The trust proved short-lived however. On December 11, 1872, a headline in the Chicago Daily Tribune on a story about the Scandinavian Bank read, "The President Squanders the Assets and Decamps." The Tribune story strongly indicated fraudulent management and also brought forth information (or at least rumors) that Winslow, together with his partner, Theo. Gelpcke, had failed with another

52. Hess, "Confiscation and the Northern War Effort," 72.

53. Ferdinand Sophus Winslow, "Til Kongen! [To the King!]," in Justitsministeriet, 1, Kontor, 1848-1967 Journalsager, 1872 Æ. 2141-2250, Rigsarkivet, Copenhagen. The Danish National Archives, Rigsarkivet, also holds the proceedings of Winslow's initial trial for document forgery and embezzlement. "77/49 [Testimony Winsløw]," in Københavns Kriminal- og Politiret, 3, Kriminalkammer, 18451919 Forhørsprotokol, December 28, 1847-October 19, 1849, Rigsarkivet (author's translation).

54. "Skandinavisk Bankir Och Vexelrörelse: Winslow \& Christensen [Scandinavian Bank and Exchange: Winslow \& Christensen]," Hemlandet, 11/1/1865. 
bank in Iowa before the war "under highly suspicious circumstances." The article's author claimed that Winslow and Gelpcke had to "hide themselves in a cellar, and afterwards flee from Dubuque to escape from the vengeance of the enraged depositors." 55

Nineteenth-century newspaper accounts were notoriously difficult to trust, yet the appearance of this information in one of Chicago's biggest newspapers indicates that stories of Winslow's checkered past circulated in Chicago after the Civil War. Perhaps most interesting is the assertion that by the time Winslow opened a bank in Chicago he claimed to be worth $\$ 25,000$. In the 1860 census, dated June 6, Winslow, listed as a "banker" living in "the Town of Anamosa" in Jones County, Iowa, had a personal estate worth $\$ 5,000$. Thus, Winslow, who was paid a captain's salary for three years during his war service between 1861 and 1864 while supporting a wife and three children, supposedly increased his net worth by $\$ 20,000$ between 1860 and 1865 . By 1870 , according to the census of 1870, Winslow lived with his wife, Wilhemina, and their four children and five servants in the town of Lake View, Illinois, with a personal estate worth $\$ 12,000$ and real estate worth $\$ 33,000.56$

In 1876 Winslow was sentenced to jail for the theft of $\$ 12,000$ from the U.S. government, thus dispelling any doubt that he did not always adhere to the law. Fraud, even according to an 1874 admission attributed to him by the Chicago Tribune after his arrest, was part of Winslow's modus operandi. "With what a heart-burning and contrition I look back upon the ruined shipwreck of life can be known only to the great Searcher of Hearts. I always knew

55. "The Scandinavian Bank: The President Squanders the Assets and Decamps," Chicago Daily Tribune, 12/11/1872.

56. "Skandinavisk Bankir Och Vexelrörelse: Winslow \& Christensen"; 1860 U.S. Census, Town of Anamosa, Jones County, Iowa, p. 23; 1870 U.S. Census, Lake View, Cook County, Illinois, p. 27. In September 1861 Winslow relocated from Anamosa to Linn County. From there he enlisted in the Ninth Iowa Infantry Regiment. According to his 1863 testimony in the court of inquiry, he left Helena on September 30,1862, because of illness and "was sick in St. Louis until the middle of February." "Proceedings and Report of a Court of Inquiry on the Sale of Cotton," 40. In 1860 Redman Stephens and Winslow started the Linn County Bank: Winslow, Stephens \& Co. in Marion, Iowa; in 1863 they applied for, and received, a charter to become the First National Bank of Linn County, Iowa. Winslow's partner, Redman Stephens, owned 330 of 500 shares of stock; Winslow, according to a local history account, did not own any shares. Marvin Oxley, The History of Marion, Iowa, 1838-1927, 5 vols. (Marion, 1995), 1:285 
what was right ... [but] when temptation came to accumulate riches, I yielded readily, and have lost my good name, have made my family miserable, have caused distress upon a wide circle." 57

A decade earlier, during the Civil War, there had been reason for optimism. General Edward Canby recommended Winslow for promotion to major during the 1865 campaign against Mobile, Alabama, and the request was approved by Commanding General Ulysses S. Grant. ${ }^{58}$ The Civil War ended one month later, however. Although Winslow rededicated himself to business by opening a bank in Chicago, the scandal surrounding his Civil War service continued to haunt him. When his Scandinavian National Bank crashed in December 1872, the Chicago Daily Tribune reminded its readers that during the Civil War Winslow had "engaged in coton [sic] speculations" and made "considerable money" doing it. 59

THE 1863 Court of Inquiry on the Sale of Cotton and Produce highlights the chaotic nature of political debates over emancipation in the late summer of 1862. Runaway slaves often lived under desperate conditions in occupied areas of the Confederacy; that was certainly the case in Arkansas. Although General Curtis did much personally to alleviate runaway slaves' hardship, the challenge of providing for them by selling cotton led to economic temptations and transactions that violated military doctrine. When white officers and merchants discovered an opportunity to improve their own pecuniary situation-indirectly at the expense of the black population within Union lines at Helenaseveral high-ranking officers in the Army of the Southwest took advantage of the opportunity. Ferdinand Winslow was central to transportation on the Mississippi River during that time, and

57. "Banking and Financial Items," The Bankers' Magazine 27 (1873), 581-82; "Winslow: A Pathetic Letter to United States Treasurer Wyman. The Treasury Robber's Biographical Sketch of Himself. How He Struggled with Poverty and Sought a Clerkship," Chicago Daily Tribune, 1/27/1877; "Winslow - His Record in Chicago," Chicago Tribune, 1/8/1877.

58. Edward Canby, “New Orleans La Mar 5th 1865," Letters Received by the Commission Branch of the Adjutant General's Office, 1863-1870, National Archives, Washington, DC.

59. "The Scandinavian Bank - the President Squanders the Assets and Decamps." See also "En Bankier Som Svindler [A Fradulent Banker]," Socialisten, 1/15/1873. 
although there is no smoking gun linking him directly to cotton trade and private profits in the court of inquiry, the fact that his personal fortune seemingly rose from $\$ 5,000$ to $\$ 25,000$ between 1860 and 1865, his admission of interest in making money off of cotton in November 1863, and his pattern of criminal offences support the circumstantial evidence found by the court of inquiry. An analysis of Ferdinand Winslow's life thus reveals that this Danish immigrant chose money over his professed commitment to abolitionism during his time at Helena, Arkansas. The same could be said of several other Union army officers. ${ }^{60}$ In the summer of 1862, the spoils of the victors benefited Curtis's officers more than they did the former slaves who helped produce them.

60. Even General Curtis expressed an interest in private monetary gain based on his position in the army. As Curtis wrote to his brother Henry on December 15,1862 , planters had sent him money "to hold till the war" was over. "If I can make a little on these deposits I would be glad to do so," Curtis wrote, "but at present while the cry is against me for having made a fortune on Cotton I better not be known as having a dime." S. R. Curtis, "St. Louis, Dec 15 1862," box 1, Papers of Samuel Ryan Curtis, 1826-1866, Huntington Library, San Marino, CA. 